DEPARTMENT OF COMMERCE AND LABOR BUREAU OF STANDARDS

S. W. STRATTON, Director

CONEERENCE

ON

\title{
THE WEIGHTS AND MEASURES OF THE UNITED STATES
}

HELD AT THE BUREAU OF STANDARDS WASHINGTON, D. C. JANUARY 16 AND 17, 1905

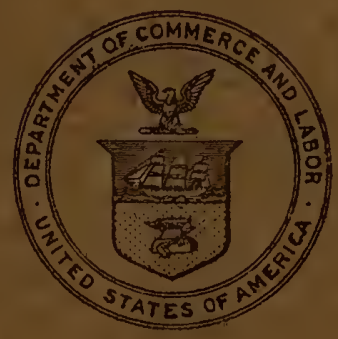

WASHINGTON

GOVERNMENT PRINTING OFFICE 1905 
t

a

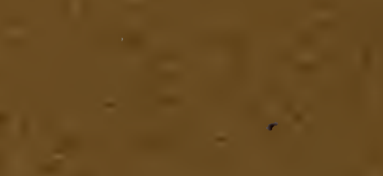

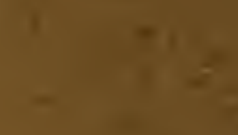

$=$

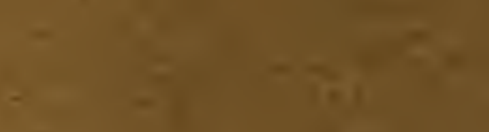

- 10

$-1-$

$x+2=$

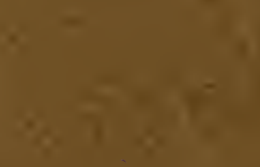

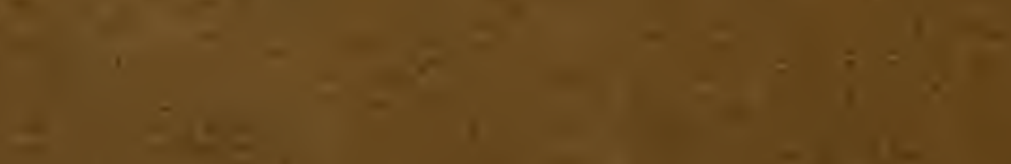

$$
\begin{aligned}
& -1-10
\end{aligned}
$$

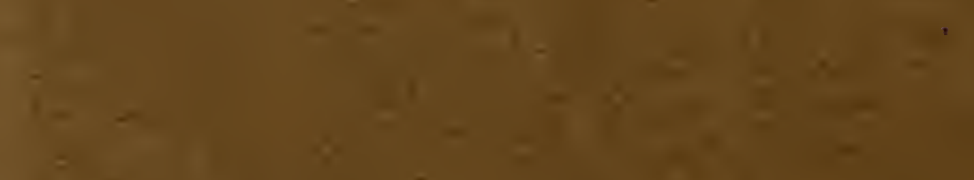




\section{DEPARTMENT OF COMMERCE AND LABOR BUREAU OF STANDARDS \\ S. W. STRATTON, Director}

\section{CONFERENCE}

ON

\section{THE WEIGHTS AND MEASURES OF THE UNITED STATES}

HELD AT THE BUREAU OF STANDARDS

WASHINGTON, D. C.

JANUARY 16 AND 17, 1905

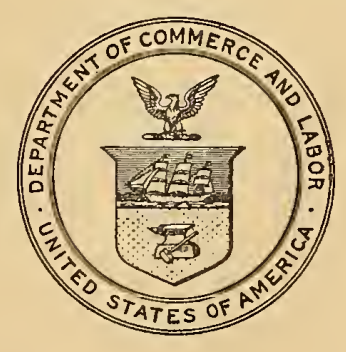

WASHINGTON

GOVERNMENT PRINTING OFFICE

1905 



\title{
LETTER OF SUBMITTAL.
}

\author{
Department of Commerce and Labor, \\ Bureau of Standards, \\ Washington, March 23, 1905.
}

SIR: I have the honor to submit herewith for publication a report of the proceedings of the First Annual Conference on the Weights and Measures of the United States, held under the auspices of the Bureau of Standards, January 16 and 17, 1905.

Respectfully,

S. W. Stratton,

Director.

The Secretary of Commerce and Labor. 



\title{
PROCEEDINGS
}

OF THE

\section{FIRST ANNUAL MEETING OF THE SEALERS OF WEIGHTS AND MEASURES OF THE UNITED STATES,}

\author{
HELD AT THE BUREAU OF STANDARDs, WASHING'TON, D. C., \\ JANUARY 16 AND $17,1905$. \\ JANUARY 16, 1905. \\ MORNING SESSION.
}

The meeting was called to order by Dr. S. W. Stratron, Director of the Bureau of Standards, who addressed the meeting as follows:

The relation between questions pertaining to standards and those arising in connection with the regulation and inspection of the weights and measures used in commerce and trade is so important that cooperation between the officials having these matters in charge is absolutely essential in order to secure uniform and efficient results. It was for this purpose that the various State custodians, inspectors, and sealers of weights and measures were invited to meet with the officials of the National Bureau of Standards, and as the representative of that institution it gives me great pleasure to welcome you to this conference, which can not fail to be productive of the utmost good, and I hope that one of the results of the meeting will be a permanent organization of the officials throughout the country intrusted with the administration of the laws pertaining to weights and measures.

In order to facilitate discussion and bring the subject clearly and concisely before you, the Bureau has compiled the laws concerning the weights and measures of the various States. A mere glance at this volume, which is before you, will show that the different States have enacted laws without regard to each other. In many cases adjacent States have laws just different enough to encourage fraud on 
the part of those dealing with the public. Furthermore, in many States the laws are not enforced, and I fear that this is true in a large majority of them. However, the country is now awakening to the necessity for uniform laws pertaining to weights and measures.

The Bureau of Standards is the successor of the Office of Weights and Measures, which formerly existed in the United States Coast and Geodetic Survey. One of the largest and most important branches of the Bureau's work is the section of weights and measures. This section has charge of the fundamental standards of length, mass, and volume, and compares with these standards the working standards of States, educational and scientific institutions, manufacturers, and others, but has no control orer local laws and regulations pertaining to the inspection or use of commercial weights and measures. Nevertheless local authorities are continually coming to us for advice in such matters, and consequently the Bureau has made a study of the subject, both in this country and abroad, has derised apparatus for the use of local officials, and lras placed these designs in the hands of manufacturers. A collection of the balances, weights, and measures used by the local inspectors in foreign countries has been made and may be seen in the rooms of the section of weights and measures.

In 1836 a law was enacted by Congress which directed that each State in the Union should be provided with a complete set of standards. In accordance with this act most of the States have been supplied with a set of standard weights and measures, but in only a few instances has any use been made of them. In most cases they are in the custody of some official whose other duties are so onerous that little or no time can be given to the inspection of the commercial weights and measures in use. In consequence of this condition the Bureau is called upon to make tests of ordinary weights and measures which should be tested by local authorities.

Delegates and their friends are invited to visit the laboratories of the Bureau. The sections devoted to thermometry, electricity, light, and engineering, instruments will be found equally interesting, although perhaps not so closely related to the subject under discussion.

Mr. L. A. Fischer, in charge of the Section of Weights and Measures of the Bureau of Standards, then read a paper on the "History of United States weights and measures," which follows:

Mr. Chalrman and Gentlenen: The subject of weights and measures is one of such great interest and importance and is attracting so much attention in this country and in England at the present time that a short account of the steps taken to secure uniformity in 
the United States is deemed an appropriate subject to bring to the attention of this convention.

The attention of the United States Government has long been directed toward securing uniformity in this country, and in the effort to secure international agreement in weights and measures it has always shown the greatest interest. The history of the original Confederation of States and of the constitutional government of the United States is full of evidences of the perplexities arising from the diversity of weights and measures throughout their jurisdiction and of the desirability of a uniform system.

The weights and measures in common use in this country at the time of the American Revolution were all of English origin and were in use in England at that period. The principal units were the yard, the avoirdupois pound, the gallon, and the bushel. More or less authentic copies of the English standards of the denominations mentioned had been brought over from time to time and adopted by the different colonies. Divergencies in these weights and measures were, however, quite common, due no doubt to the fact that the system of weights and measures of England was not itself well established, and hence the copies brought to this country were often adjusted to different standards.

That this condition was recognized very early is made evident by the Articles of Confederation, which contained the following clause: "The United States in Congress assembled shall also have the sole and exclusive right and power of regulating the alloy and value of coin struck by their own authority, or by that of the respective States-fixing the standard of weights and measures throughout the United States." This power was transferred to Congress by the Constitution of the United States in Article I, section 8, the language being as follows: "The Congress shall have Porer * * * To coin Money, regulate the Value thereof, and of foreign Coin, and fix the Standard of Weights and Measures;".

While Congress was not slow to take action in regard to coinage, it seems not to have been inclined to come to a decision in regard to weights and measures, though apparently willing enough to consider the subject. Washington, in his first annual message to Congress, January, 1790, stated that "uniformity in the currency, weights, and measures of the United States is an object of great importance, and will, I ain persuaded, be duly attended to." In accordance with Washington's suggestion, the matter was referred to a select committee of the House of Representatives with instructions to prepare a bill, and it was also ordered that the matter be referred to the $3043-05$ ม1- 2 
Secretary of State to prepare and report to the House a proper plan for establishing uniformity in the reights and measures. Jefferson was then Secretary of State, and in response to the above request made a report, in which he proposed two distinct plans. The first was substantially to "define and render uniform and stable the existing system *** to reduce the dry and liquid measures to corresponding capacities by establishing a single gallon of 270 cubic inches and a bushel of eight gallons, or 2,160 cubic inches * * *" The second plan was "to reduce every branch to the same decimal ratio already established for coin, and thus bring the calculations of the principal affairs of life within the arithmetic of erery man who can multiply and divide plain numbers."

To action was taken, however, by the House, and in his second message to Congress, on December 8, 1790, Washington again called the attention of that body to the importance of the subject. A few days later the House ordered that the report of Jefferson, referred to abore, be communicated to the Senate. 'On March 1, 1791, the Senate committee to which the matter had been referred reported that it would not be eligible to make a change in the weights and measures, as a proposition had been made to the French and British Gorernments to obtain an international standard. This report was accepted and the matter rested there, although Washington, on October 25. 1791. repeated his former recommendations in his third annual message to Congress, in the following language:

A uniformity in the weights and measures of the country is among the important objects submitted to sou by the Constitution and if it can be derived from a standard at once inrariable and unirersal, must be no less honorable to the public councils than conducire to the public conrenience.

A week later the Senate appointed a committee to take into consideration the subject of weights and measures. The committee reported on the th of April, 1792, recommending the adoption of the second plan proposed by Jefferson, which was an entirely decimal system. Again no definite action was taken. The matter was considered in a desultory way by Congress from time to time, but no agreement was reached notwithstanding that the repeated recommendations of Washington were followed by those of Adams. A sufficient explanation for the disinclination of Congress to act in a matter of such admitted importance was the difficulty of agreeing upon a plan.

The Fifth Congress, second session, in 1799, passed an act ordering that the surreyor (of each port of the United States) shall from time to time, and particularly on the first Monday of January and July in 
each year, examine and try the weights, measures, and other instruments used in ascertaining the duties on imports with standards to be provided by each collector at the public expense for that purpose; and when disagreements and errors are discovered he shall report the same to the collector and obey and execute such directions as he may receive for the correction thereof agreeably to the standards a foresaid.

This was the first act passed by Congress in regard to weights and measures, but in view of the fact that no standards had ever been adopted the legislation was not put into operation until about thirtyfive years after its passage, when certain standards, which will be referred to later, were adopted by the Treasury Department.

After the war of 1812 the question of uniformity in weights and measures was again brought to the attention of Congress, and in 1819 a committee of the House of Representatives proposed to adopt absolute standards conforming to the weights and measures in common use; to obtain through a commission copies of the yard, the bushel, the wine gallon, and the pound supposed to conform to those in common use in the United States; to preserve these standards and to distribute copies of them; to compare the length measure with the length of the second's pendulum and also with that of an arc of the terrestrial meridian; to connect them by determining the weight of a certain bulk of distilled water, and to define the bushel and the gallon by the weight of water which they contain. No further record of the report is found, and it may be assumed that no action upon it was taken. The Senate had, by a resolution adopted March 3, 1817-two years prior to the above report-requested the Secretary of State to prepare and report a "statement" relative to the regulations and standards for weights and measures in the several States and relative to the proceedings in foreign countries for establishing uniformity in weights and measures, together with such propositions relative thereto as might be proper to adopt in the United States.

John Quincy Adams was at that time Secretary of State, and four years later-namely, on February 22, 1821-he submitted an elaborate report to the House of Representatives, in which, among other recommendations, the following are found:

(1) To fix the standard with the partial uniformity of which it is susceptible for the present, excluding all innovations.

(2) To consult with foreign nations for the future and ultimate establishment of universal and permanent uniformity.

As before, Congress took no action, probably because the situation at that time was extremely complicated. Neither the metric system 
in France nor the system in common use in England was well established. In France the law making the metric system compulsory had been repealed, and the metric system was in use side by side with the ancient weights and measures, thus producing endless confusion. In England the situation was not much better; the ale gallon of 282 cubic inches and the wine gallon of 231 cubic inches were both in use until 182t, when the new imperial gallon, containing 10 pounds of water, and of a capacity of about $277 \frac{1}{4}$ cubic inches, was adopted, together with the bushel of 8 gallons. Neither of these measures was in use in this country, and hence the United States could not at that time adopt either of the systems in use in England or France without introducing radical changes in the weights and measures alleady in use, nor was there at that time any positive assurance that either the English or metric systems would be permanent.

While Congress had been considering the matter, most of the States bad, independently of one anothèr, secured and adopted standards. Most of the standards thus adopted were brought from England; nevertheless, standards of the same denomination differed widely among themselves, thus perpetuating confusion in the cominerce between adjacent States.

Though confusion in commercial transactions might be overlooked, uncertainty in regard to the coinage could not be tolerated, and on May 19, 1828, a certain troy pound was adopted as the standard for coinage by Congress in an "Act to continue the Mint at the City of Philadelphia, and for other purposes." The section 2 of the act referred to reads as follows:

And be it further enactcd, That, for the purpose of securing a due conformity in weight of the coins of the United States **** the brass troy pound weight procured by the minister of the United States at London, in the year one thousand eight hundred and twenty-seren, for the use of the Mint, and now in the custody of the Mint at Philadelphia, shall be the standard troy pound of the Mint of the United States, conformably to which the coinage thereof shall be regulated.

The troy pound thus adopted had been procured in the year 1827 by Albert Gallatin. minister of the United States at London, and brought to this country by special messenger, who delivered it to the director of the Mint at Philadelphia. The weight was of brass and an exact copy of the imperial troy pound of Great Britain, according to the statement of Captain Kater, who made the comparison between the two standards. The casket and accompanying packages were retained under seal until Mr. Adams, President of the United States, 
visited Philadelphia and verified the seal of Mr. Gallatin and the other facts in regard to its authenticity.

This ceremony took place on October 12, 1827, and the full certificate of President Adams in regard to the seal, which he readily recognized, and to the whole transaction and consequent accuracy of the weight was added to the vouchers in the case. He declared, in conclusion, his belief that the brass weight then exhibited was the identical pound copy of the imperial standard troy pound of Great Britain referred to in the aforesaid certificates. The foregoing facts were communicated to Congress through the Committee on the Mint and resulted in the passage of the act cited above.

While the act of Congress of 1828 only made this pound the standard for coinage, it virtually became the fundamental standard of the United States from which the avoirdupois pound in common use was derived.

On May 29, 1830, two years after the mint pound had been legalized for coinage, the Senate passed a resolution directing the Secretary of the Treasury to cause a comparison of the weights and measures in use at the principal custom-houses to be made, and to report to the Senate at its next session.

Steps were promptly taken by the Treasury Department to comply with the resolution of the Senate, and the preliminary report of $F$. R. Hassler, Superintendent of the Coast Survey, to whom the investigation had been intrusted, was transmitted to the Senate on March 3, 1831, this being followed by a more complete report in June, 1832.

As was anticipated, large discrepancies were found to exist among the weights and measures in use at the different ports, some being too small and others too large, but the average value of the various denominations agreed fairly well with the weights and measures in use in Great Britain at the time of the American Rerolution.

Without waiting for authority from Congress the Treasury Department took immediate steps to correct the evil by having constructed, under the direction of Mr. Hassler, the necessary weights and measures for the customs service. The dirergencies among the weights and measures in use in the customs service was directly opposed to the spirit of the Constitution, which requires that all duties, imposts, and excises shall be uniform throughout the United States, and the Secretary of the Treasury felt fully authorized in taking steps to secure uniformity when discrepancies were once known to exist.

Before weights and measures could be constructed, however. it was necessary for the Treasury Department to determine upon certain 
units and to adopt material representatives of these units. Those finally adopted were the yard of 36 inches, the avoirdupois pound of 7,000 grains, the gallon of 231 cubic inches, and the bushel of 2,150.42 cubic inches. The standard yard adopted was the 36 inches comprised between the twenty-seventh and the sixty-third inches of a certain 82-inch brass bar, prepared for the Coast Survey by Troughton, of London. This bar had been brought to the United States by Hassler in 1813, and the 36-inch space referred to was supposed to be identical with the English standard at $62^{\circ} \mathrm{F}$., though it had never been directly compared with that standard.

It is evident from the reports of Mr. Hassler that he regarded the imperial yard as the real standard of length of the United States and the Troughton scale merely as a copy whose length should be corrected if it was subsequently found to differ from the imperial yard; and this view was taken by those who subsequently had charge of our. standards, as will be shown later on.

The avoirdupois pound adopted by Mr. Hassler as the standard for the Treasury Department was derived from the troy pound of the mint according to the equivalent, 1 a voirdupois pound equals $\frac{7}{6} \frac{0}{7} \frac{0}{6}$ pounds troy. This was the accepted relation in this country as well as in England; hence both the troy and avoirdupois pounds adopted were in practical accord with the similar standards of Great Britain.

The units of capacity, namely, the wine gallon of 231 cubic inches and the Winchester bushel of 2,150.42, were adopted, because, as intimated, they represented more closely than any other English standards the average of the capacity measures in use in the United States at the date of Mr. Hassler's investigation. The wine gallon was introduced as a wine measure into England in 1707, during the reign of Queen Anne, but it was abolished in 1824, when the new imperial gallon, containing 10 pounds of water, was made the standard. This last statement applies also to the bushel of $2,150.42$ cubic inches. This bushel is the earliest English capacity measure of which we have any record, a copy of it made by order of Henry VII being still in existence. But this bushel had also been abolished in England, it having been superseded by the bushel of 8 gallons. Therefore neither the gallon nor the bushel adopted by the United States Treasury Department was in accord with the legal capacity standards of England, but they differed by about 17 per cent and 3 per cent, respectively, and these differences exist at the present time. Not only did they differ from the new standards in Great Britain, but they also differed from the discarded English standards from which they were derived, for the reason that Mr. Hassler selected the teniperature of the maximum 
density of water, namely, $39.2^{\circ} \mathrm{F} .{ }^{a}$ as the temperature at which the United States measures were standard, whereas their English prototypes were standard at $62^{\circ} \mathrm{F}$.

Such, then, were the fundamental standards adopted upon the recommendation of $\mathrm{Mr}$. Hassler by the United States Treasury Department, and according to which the weights and measures for the customs service were made to conform. The construction of the weights and measures for this purpose was pushed with almost feverish haste, and so well satisfied was Congress with the progress made that the following act was passed and approved June 14, 1836 :

Resolved by the Senate and House of Representatives of the United States of Ameriea in Congress assembled, That the Secretary of the Treasury be, and he hereby is, directed to cause a complete set of all weights and measures adopted as standards and now either made or in progress of manufacture for the use of the several custom-houses, and for other purposes, to be delivered to the governor of each State in the Union, or such person as he may appoint for the use of the States, respectively, to the end that a uniform standard of weights and measures may be established throughout the United States.

While the act does not specifically adopt the standards above described, the practical effect of it was to make them the standards for the United States, inasmuch as the weights distributed to the States in accordance with the act were in almost every case adopted by the State legislatures soon after their receipt.

The act of 1836 was supplemented in 1838 by a joint resolution of Congress, which directed the Secretary of the Treasury to furnish balances to the States. By 1838 the weights for the States were reported finished, and during the following year the weights for the custom-houses were completed and delivered.

By 1850 practically all the States admitted to the Union had been supplied with complete sets of weights and measures, and in addition sets were presented to England, France, Japan, and Siam. As new States were admitted they were also supplied with sets of standards, the last set being supplied to North Dakota in 1893.

In order to carry out the provisions of the acts of 1836 and 1838 the Office of Weights and Measures, under the direction of the Superintendent of the Coast Survey, had been established, and all the standards adopted at the beginning of the work, and subsequently, were in charge of this Office, with the exception of the troy pound of the mint, which has always remained at Philadelphia.

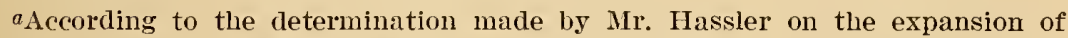
water, $39.83^{\circ} \mathrm{F}$. was the temperature of maximum density. See report of Alexander D. Bache, Superintendent of Weights and Measures, 46-47. Ex. Doc. No. 73, 30th Cong., 1st sess. 
In October, 1834, the British imperial yard and troy pound made in 1758, of which the Troughton scale and the mint pound were supposed to be exact copies, were destroyed by the burning of the Houses of Parliament. When the new imperial standards to replace them were completed in 1855 two copies of the yard and one copy of the avoirdupois pound were presented to the United States, arriving in this country in 1856. One of these bar's, namely, bronze yard No. 11, was very soon after compared with the Troughton scale, the result showing that the accepted 36 inches of the Troughton scale was 0.00087 inch longer than the British imperial yard. The second bar received from England was subsequently compared with the Troughton scale and fully corroborated the result obtained from the comparison with bronze No. 11. The new yards, and especially bronze No. 11, were far superior to the Troughton scale as standards of length, and consequently they were accepted by the Office of Weights and Measures as the standards of the United States, and all comparisons were afterwards referred to the imperial yard throngh these two standards. They were twice taken to England and recompared with the imperial yard, once in 1876 and again in 1888 .

The avoirdupois pound presented with the two yards was also compared with the United States avoirdupois pound derived from the mint pound, the result showing a very satisfactory agreement. The advent of the new pound did not, therefore, disturb the position of the troy pound of the mint or of the avoirdupois pound derived from the mint pound.

The next and perhaps the most important legislation enacted by Congress was the act of 1866 legalizing the metric system of weights and measures in the United States. The act, which was passed July 28,1866 , reads as follows:

Be it enacted by the Senate and House of Representatives of the United States of America in Congress assembled, That from and after the passage of this act it shall be lawful throughout the United States of America to employ the weights and measures of the metric system, and no contract or dealing or pleading in any court shall be deemed invalid or liable to objection because the weights or measures expressed or referred to therein are weights or measures of the metric system.

SEc. 2. And be it further enacted, That the tables in the schedule hereto annexed shall be recognized in the construction of contracts and in all legal proceedings as establishing in terms of the weights and measures now in use in the United States the equivalents of the weights and measures expressed therein in terms of the metric system; and said tables may be lawfully used for computing, determining, and expressing in customary weights and measures the weights and measures of the metric system. 
Measures of length.

\begin{tabular}{|c|c|}
\hline Metric denominations and values. & Equivalents in denominations in use. \\
\hline 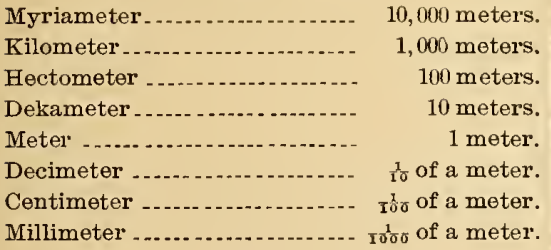 & 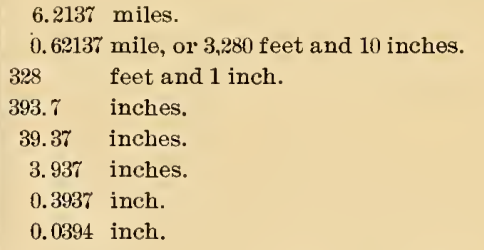 \\
\hline
\end{tabular}

Measures of capacity.

\begin{tabular}{|c|c|c|c|c|}
\hline \multicolumn{3}{|c|}{ Metric denominations and values. } & \multicolumn{2}{|c|}{ Equivalents in denominations in use. } \\
\hline Names. & $\begin{array}{l}\text { Num- } \\
\text { ber of } \\
\text { liters. }\end{array}$ & Cubic measure. & Dry measure. & $\begin{array}{l}\text { Liquid or wine } \\
\text { measure. }\end{array}$ \\
\hline Kiloliter or stere. & 1,000 & 1 cubic meter & 1.308 cubic yards _... . . & 264.17 gallons. \\
\hline Hectoliter ..... & 100 & $\frac{1}{10}$ of a cubic meter .... & 2 bushels and 3.35 pecks. & 26.417 gallons. \\
\hline Dekaliter ....... & 10 & 10 cubic decimeters ..- & 9.08 quarts $\ldots \ldots \ldots$ & 2.6417 gallons. \\
\hline Liter ........ & 1 & 1 cubic decimeter .... & 0.908 quart & 1.0567 quarts. \\
\hline Deciliter ... & $\frac{1}{10}$ & ro of a cubic decimeter. & 6.1022 cubic inches....... & $0.845 \mathrm{gill}$ \\
\hline Centiliter ... & $\frac{1}{100}$ & 10 cubic centirneters .- & 0.6102 cubic inch & 0.338 fluid ounce. \\
\hline Milliliter .... & Iror & 1 cubic centimeter .... & 0.061 eubic inch & 0.27 Huid dram. \\
\hline
\end{tabular}

Measures of surface.

\begin{tabular}{|c|c|}
\hline Metric denominations and values. & Equivalents in denominations in use. \\
\hline $\begin{array}{l}\text { Hectare } \\
\text { Are } \\
\text { Centare }\end{array}$ & $\begin{array}{l}2.471 \text { acres. } \\
119.6 \text { square yards. } \\
1,550 \quad \text { square inches. }\end{array}$ \\
\hline
\end{tabular}

Weights.

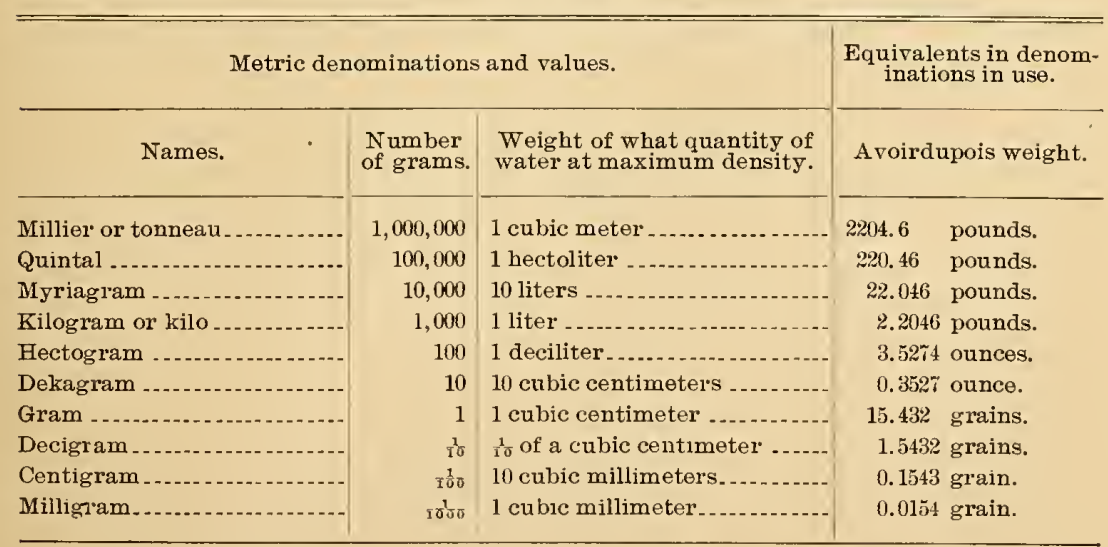

$3043-05 \mathrm{M}--3$ 
While the above resolution was being considered, Congress also considered a bill authorizing the Secretary of the Treasury to furnish the States with metric weights and measures. Strange to say, this bill, which logically should follow, was approved one day before the resolution legalizing the use of the metric system. It was likewise a joint resolution, and read as follows:

Be it resolved by the Senate and House of Representatives of the United Stales of Ameriea in Congress assembled, That the Secretary of the Treasury be, and he is herebs, authorized and directed to furnish to each State, to be delirered to the governor thereof, one set of standard weights and measures of the metric system for the use of the States, respectively.

The work of making and adjusting these standards fell naturally upon the Office of Weights and Measures, and the first question that had to be considered was that of standards. The practice followed by other countries which had adopted the metric system of accepting the meter and the kilogram of the archives of France as fundamental standards was followed by the United States. The question was mainly one of securing authentic copies of these standards. Fortunately the Office of Weights and Measures had several copies of both standards of more or less authenticity on hand, but without hesitation an iron bar, known as the "committee meter," and a platinum kilogram, known as the "Arago kilogram," were selected.

The committee meter is one of fifteen similar bars, whose lengths were ascertained in the process of constructing the original meter by the French committee of weights and measures in 1799; hence its name, "committee meter."

The committee referred to was composed of members of the National Institute of France and of deputies from foreign countries. Mr. J. G. Tralle, the deputy from the Helvetic Republic, had been placed in charge of the construction of the meters, and when the bars were distributed among the members of the committee he secured two of them, one of which he presented to Mrr. Hassler. This bar was therefore of the highest authenticity. As before stated, it is made of iron, with a cross section of 9 by $29 \mathrm{~mm}$., and its length is defined by the end surfaces, which are remarkably plane when one considers the age in which the bars were made. The bar bears the stamp of the committee. namely, a small ellipse, whereof three quadrants are shaded and the fourth one clear, except for the number $10,000,000$, which indicates the number of meters in a meridian quadrant of the earth. It also bears the mark $\therefore$ at one end, by which it was distinguished during the comparison with the other meters. In Mr. Hassler's report on the construction of the meters it is stated, on 
the authority of Mr. Tralle, that all the meters agreed with the true meter within one-millionth part of the toise ${ }^{a}$

When Mr. Hassler came to the United States in 1805 he brought with him the committee meter, which he soon after presented to the Philosophical Society of Philadelphia, Pa. Shortly after, when he was put in charge of the survey of the coast, the meter was placed at his disposal by the Philosophical Society, and he made it the standard of length for that work, and until 1890 all base measurements of the Survey were referred to this meter.

In view of the foregoing, it was but natural that this bar should be selected as the standard to which the State meters should conform.

The Arago kilogram was procured in 1821 by Mr. Gallatin while minister of the United States to France and was sent to this country, together with a platinum meter. The certificate of Arago, the celebrated physicist, which accompanied these standards, states that the kilogram differs from the original kilogram des Archives by less than $1 \mathrm{mg}$. The weight is a platinum cylinder with flat bases, the edges being slightly rounded. The height and diameter are nearly equal, being approximately $39.5 \mathrm{~mm}$ each. There is no stamp or distinguishing mark of any kind, except near the center of one base there is a faint lathe or tool mark of circular form, thus: $\odot$. The weight is contained in a square mahogany box, on the cover of which is a circular silver plate bearing the inscription "Kilogramme comparé pour son Poids a l'Etalon Prototype des Archives de France, et verifié par M. Arago. Fortin fecit." No particulars of Arago's comparison with the kilogram des Archives were furnished, and consequently it is not known what means were used by him in making his comparison nor whether he reduced his weighings to vacuo. It was not until 1879 that the Arago kilogram was compared with any other standards of recognized authority. It is true that it was compared between 1852 and 1873 with a couple of kilograms in the possession of the Office of Weights and Measures, but as both of these weights were of brass and of unknown density, no great reliance could be attached to the results. In 1879 , however, it was taken to England and there compared with the British platinum kilogram in the custody of the Standards Office. This comparison indicated that the Arago kilogram was $4.25 \mathrm{mg}$ light, but this result could not be considered conclusive, on account of certain assumptions made in the

$a$ The toise was the French standard of length prior to the adoption of the meter, and all the measurements upon which the meter is based were made with the toise. Its length is $1.949+$ meters. 
reduction to vacuo and also in regard to the correction to the British kilogram.

In 1884 the weight was taken from the Standards Office in London, where it had been since 1879, to the International Bureau of Weights and Measures at Paris, and there compared with two auxiliary kilograms whose values in terms of the kilogram of the Archives were known with the greatest accuracy. The results obtained from the comparison confirmed that previously obtained from the comparison with the British kilogram, the result giving

$$
K \hat{\imath}=1,000 \mathrm{~g}-4.63 \mathrm{mg} .
$$

As the weights supplied to the States were to be made of brass, it was more convenient to compare them with a brass standard, and in order to do this two secondary brass standards were carefully compared between the years 1873-1876 with the Arago kilogram and afterwards used in all the work of adjustment and verification. One of the kilograms, known as the Silbermann kilogram, was presented to the United States by France in 1852, together with a number of other weights and measures. The other kilogram used was one made in the Office of Weights and Measures and was identical in form and material with the kilograms subsequently furnished to the States.

The unit of capacity in the metric system being defined as the volume of the mass of 1 kilogram of pure water at the temperature of maximum density, the most convenient way to adjust such measures, and in fact all capacity measures, is by weighing the water they contain. The only two material standards that need to be considered, therefore, in connection with the metric weights and measures furnished to the States in accordance with the act of 1866 are the committee meter and the Arago kilogram described above.

By the end of 1880 practically all the States had been supplied with sets of metric weights and measures consisting of the following denominations:

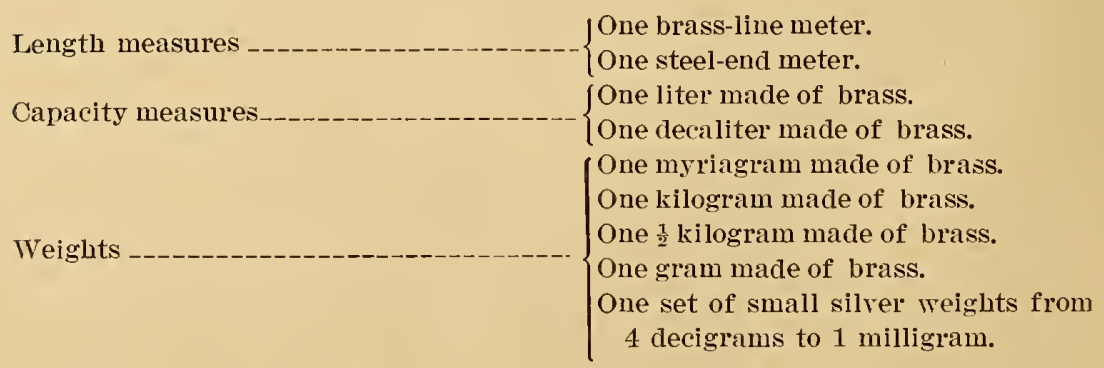


It is necessary at this point to go back a few years and give an account of the establishment of the International Bureau of Weights and Measures, since the present fundamental standards of length and mass for the civilized world result from the establishment of that institution.

In response to an invitation of the French Government, the following countries sent representatives to a conference held in Paris on August 8, 1870, to consider the advisability of constructing new metric standards :

$\begin{array}{lll}\text { Austria, } & \text { Italy, } & \text { Spain, } \\ \text { Ecuador, } & \text { Norway, } & \text { Switzerland, } \\ \text { France, } & \text { Peru, } & \text { Turkey, } \\ \text { Great Britain, } & \text { Portugal, } & \text { United States, } \\ \text { Greece, } & \text { Russia, } & \text { Colombia, }\end{array}$

in all 15 countries. This conference was of short duration, on account of the war then raging between France and Germany.

A second conference was held two years later, at which 30 countries were represented, the United States again being among this number. At this conference it was decided that new meters and new kilograms should be constructed to conform with the standards of the Archives, and a permanent committee was appointed to carry out this decision. The preparation of the new standards had advanced so far by 1875 that the permanent committee appointed by the conference of 1872 requested the French Government to call a diplomatic conference at Paris to consider whether the means and appliances for the final verification of the new meters and kilograms should be provided with a view to permanence, or whether the work should be regarded as a temporary operation.

In compliance with this request a conference was held in March, 1875 , at which 19 countries were represented, the United States as usual being of this number.

On May 20,1875, 17 of the 19 countries represented signed a convention which provided for the establishment and maintenance of a permanent International Bureau of Weights and Measures to be situated near Paris and to be inder the control of an international committee elected by the conference, the committee to consist of 14 members, all belonging to different contries.

In addition to the primary work of verifying the new metric standards the bureau was charged with certain duties, the following being the most important:

(1) The custody and preservation, when completed, of the international prototypes and auxiliary instruments. 
(2) The future periodic comparison of the several national standards with the international prototypes.

(3) The comparison of metric standards with standards of other countries.

The expenses of the bureau were to be defrayed by contributions of the contracting Governments, the amount for each country depending upon the population and upon the extent that the metric system was in use in the particular country.

In accordance with the terms of the convention the French Government set aside a plat of ground in the park of St. Cloud, just outside of Paris, and upon this ground, which was declared neutral territory, the International Bureau of Weights and Measures was established.

The construction of the meters and kilograms had been intrusted to a special committee, and early in 1887 the committee completed its work and the new meters and kilograms were turned over to the International Bureau for comparison with the standards of the Archives and with one another.

It had been decided as early as 1873 that the new standards should be made of an alloy of 90 per cent platinum and 10 per cent iridium, and that the meters should be line standards of the " $X$ " cross section. Altogether 31 meters and 40 kilograms were constructed.

By 1889 the entire work was completed, and in September of that year a general conference was held at Paris, and by it the work of the international committee was approved.

The meter and kilogram which agreed most closely with the meter and kilogram of the Archives were declared to be the international meter and the international kilogram. These two standards, with certain other meters and kilograms, were deposited in a subterranean vault under one of the buildings of the International Bureạu, where they are only accessible when three independent officials with different keys are present. The other standards were distributed by lot to the various Governments contributing to the support of the International Bureau. Those falling to the United States were meters Nos. 21 and 27 and kilograms Nos. 4 and 20.

Meter No. 27 and kilogram No. 20 were brought under seal to this country by Mr. George Davidson, of the Coast and Geodetic Survey, and on January 2, 1890, they were opened at the White House and accepted by President Harrison, who certified that they were received in good condition, and that he confidently believed that they were the standards referred to in the report. The other two standards were 
received the following July and were deposited in the Office of Weights and Measures, where those accepted as national standards by the President had already been taken. ${ }^{a}$ On April 5, 1893, the Superintendent of Weights and Measures, with the approval of the Secretary of the Treasury, decided that the international meter and kilogram would in the future be regarded as the fundamental standards of length and mass in the United States both for metric and customary weights and measures.

This action did not in any way affect the metric weights and measures of the United States inasmuch as the meter and kilogram of the Archires had always been regarded as our fundamental metric standards, and the international meter and kilogram had identical values so far as could be determined by the most refined measurements.

The effect of this decision on the customary weights and measures also left them practically undisturbed. All comparisons made immediately prior to 1893 indicated that the relation of the yard to the meter fixed by the act of $1866^{b}$ was by chance the exact relation between the international meter and the British imperial yard within the error of observation. A subsequent comparison made between the standards just mentioned indicates that the legal relation adopted by Congress is in error by one ten-thousandth of an inch; but in view of the fact that certain comparisons made by the English Standards Office between the imperial yard and its authentic copies show rariations as great. if not greater, than this, it can not be said with certainty that there is a difference between the imperial yard of Great Britain and the United States yard derived from the meter.

The case of the pound was slightly different, inasmuch as the relation of the kilogram to the pound, fixed by the act of 1866, was only approximate. In the act mentioned the kilogram was stated to be equal to 2.2016 pounds a voirdupois; but as 2.204622 was known to be a more precise value, and since it did not conflict with the legal ralue the avoirdupois pound was declared to be equal to $\frac{1}{2.204622}$ kilograms.

Neither the troy pound of the mint nor the copies of the imperial yard in the possession of the Office of Weights and Measures were satisfactory standards. The mint pound is made in tro pieces, the knob being screwed into the body; hence its density can not be deter-

a Upon the establishment of the Bureau of Standards on Juls 1, 1901, all standards and other property in possession of the Office of Teights and Measures passed under the control of the Bureau of Standards.

$b$ The ralue of the sard, in accordance with the above declaration, is 1 sard= $\frac{3500}{3937}$ meter. 
mined by weighing in water on account of danger of leakage. Moreorer, it is made of brass not plated, and therefore liable to alteration by oxidation.

The bronze rard No. 11, which was an exact copy of the British imperial yard both in form and material, had shown changes wher compared with the imperial yard in 1876 and 1888 which could unt reasonably be said to be entirely due to changes in No. 11. Suspicion as to the constancy of the length of the British standard was therefore aroused.

On the other hand, the new meters and kilograms represented the most advanced ideas of standards, and it therefore seemed that greater stability in our weights and measures as well as higher accuracy would be secured by accepting the international meter and kilogram as fundamental standards.

Time has amply proved the wisdom of this action, and therefore when the Bureau of Standards was established in July, 1901, the decision made by the Office of Weights and Measures in 1893 to adopt the meter and kilogram as fundamental standards was fully accepted by this Bureau.

In conclusion I wish to state that in preparing so brief an account of so great a subject many matters of importance and interest have necessarily been omitted. but if I hare succeeded in giring you an outline of the gromth of our reights and measures I shall have accomplished all that I had in mind when this paper was prepared.

Remarks of Mr. Daxiel C. V. Palirer, Deputy Sealer of Weights and Measures of the State of Massachusetts.

Mr. Chatruar and gextlemex: The standard meights and measures of Massachusetts are in the possession of the treasurer of the Commonwealth. He is charged with their proper care and custody by law, and they consist of the standards furnished by the National Government in 1843 and such additions as have since been made at the expense of the State.

The treasurer, who is elected annually by popular rote, and who can not continue in office for more than five consecutive years, is the sealer of the Commonwealth.

The duties pertaining to weights and measures are prescribed by law and are delegated by the treasurer to a "deputy sealer of weights and measures," appointed by him. The deputy is prorided with an office at the State capitol, in which are located all of the standards of the Commonwealth. He is paid by salary and is allowed the necessary expenses of travel, etc., incurred in the official performance 
of his duties, no fees being charged for work performed by him. Certain duties are required of him by law, to wit:

First. It is his duty to inspect and adjust once in five years, or oftener if desired, the sets of standard weights and measures furnished without cost to the various cities and towns by the Commonwealth. These sets consist of standards of dry, liquid, and linear measure, with a complete set of weights and finely constructed balances, with a capacity of 50 pounds, all contained in an oak case with sliding glass front. These standards are placed in the custody of the local treasurer, who is charged by law with their proper care, and are used for the purpose of comparing the working sets of the local sealers of weights and measures.

Second. He is authorized to make inspections in any locality to ascertain if the local officers are properly performing their work, and if a violation of the law is found he may, if he sees fit, make a prosecution.

The city and town sealers and deputy sealers of weights and measures are appointed annually by the mayor of the city or the selectmen of the town. They receive from the local treasurer, at the expense of the city or town, one or more duplicate sets of standards, to be used as working sets, together with suitable seals, tools, record books, etc. They then proceed to work by giving notice to all persons to bring their weights and measures to the office of the sealer, to be tested and sealed. This office is conveniently located and is equipped with suitable conveniences for the purpose of testing, etc. After waiting a reasonable time they proceed to the places of business of all persons who have neglected to comply with his notice and inspect their weights and measures. Articles tested and found to be correct are sealed; those which are incorrect, but which can be adjusted, are marked with a "Condemned" tag, which is removed by the sealer after the defect which the test showed has been removed. Articles which are incorrect, and which can not be adjusted, are stamped "Condemned" in such a manner that it can not be detached. Suitable penalties are provided for the use of scales, measures, etc., which are unsealed or which have been condemned.

The local inspection by the State official has a tendency to keep the local officials constantly on the alert. A large proportion of the false weights and measures in use are found among the hawkers and peddlers, who resort to varied and original methods of alteration. Some of the seizures show spring balances with movable fronts, dry and wet measures with false bottoms and sides, and many other specially constructed devices for fraudulent use. It would be useless to 
estimate the loss to the purchaser from the use of false weights and measures, and in many instances this loss falls on the poorer class of people, who can least afford it. To illustrate the necessity of legislation in States in which no attempt at inspection is now made, I will cite the following instance: When special legislation was passed in Massachusetts several years ago for the inspection of stramberry boxes and the sealing of milk jars and bottles, to which previously no attention had been paid, thousands of the so-called "short" boxes and bottles, which did not meet with the requirements of the law, were shipped to an adjoining State, in which little or no attempt was made to inspect weights and measures.

Although the Massachusetts law was of much earlier origin, no attempt was made at a general enforcement of the same until 1890. Since that date such changes and additions have been made in the statutes as experience and practice showed necessary, until at the present time, with a few exceptions, I believe that we have a good and practical law.

I will cite these exceptions, in order that States about to establish legislation may be benefited:

First. The State should create a separate and distinct office for this work, the person in charge to be known as the State sealer, who should be appointed by and be responsible to the governor. This system has been adopted and is now in force in the State of Rhode Island and gives entire satisfaction.

Second. The office of sealers in the cities and towns should be placed in the civil-service list and a suitable examination required, with a view to obtaining persons who are entirely competent for the work.

I would also recommend that these officers be required to make an annual report of work performed to the State sealer.

Third. That no fees whatever should be charged for the inspection and sealing of weights and measures, the local officer being remunerated by a salary consistent with the work required, to be paid from the city or town treasury. The work performed by this officer is in the nature of a protection to all inhabitants, and the cost of maintenance, in my opinion, should be paid from the public fund. This system rould also increase the efficiency of the local inspection, as it would allow tests to be made in suspicious cases several times during the year instead of annually.

The importance of a State supervision in these matters can best be realized when you consider that scarcely a commodity is bought or sold in which weights and measures do not enter into the transaction, 
and when systematic and thorough inspections are not made the public is to a large extent at the mercy of the unscrupulous dealer.

There is also a great necessity for national legislation in relation to certain commodities shipped in original packages for interstate trade, and which can not be governed by State regulation. I will, however, only refer to this, as I understand the Bureau of Standards has this matter under consideration.

Any further information as to the Massachusetts law and its enforcement will be cheerfully furnished on application by mail to the State sealer, at room 230, State House, Boston, Mass.

Remarks of Prof. Laenas G. Weld, State Superintendent of Weights and Measures, of Iowa.

GentLenen: I assure you that this is entirely extemporaneous, and I have brought nothing with me in the way of illustrative material. The laws of Iowa are tabulated in the publication just presented to us, and it is, therefore, unnecessary for me to discuss them in detail. This tabulation of the laws of the several States relating to weights and measures seems to me to be a step of the greatest importance in this connection, and one which will certainly be helpful in securing uniformity in legislation along these lines. We have already seen in the merely cursory examination of the volume that it is full of suggestions; for there are certainly excellent features in the laws regulating the matters of present interest to us in each of the several States.

The situation in Iowa with respect to the office of State superintendent of weights and measures is unique. The town of Iowa City was our first State capital. Upon the removal of the capital to Des Moines, in 1857, the grounds and buildings vacated were turned over to the State University, and are still a part of its realty. The old capitol building, the corner-stone of which bears the date July 4, 1840 , is now the administrative building of the university. Before the removal of the capital there had been built upon its grounds a little fireproof vault, in which the standards of weights and measures were kept. This still stands on the campus of the university, and is still devoted to its original use. For it was provided in the constitution of the State that the State superintendent of weights and measures should be "appointed by the governor from the board of professors of the university, to hold his office during the pleasure of the governor, and to give bond in the penal sum of $\$ 5,000$ for the faithful discharge of his duties." My predecessor, as professor of 
mathematics in this institution, had held the office for many years, and kindly passed its duties and emoluments to me. These emoluments being very modest, the duties are naturally very light. In fact, as matters stand, there is very little to be done. The vault in which the standards are kept is a brick structure about 24 feet square and practically fireproof. It is now in the shadow of large buildings, and its use is scarcely known even to the students of the university. In fact, the building is shrouded in a sort of mystery, and even has the reputation of being haunted. It is, nevertheless, kept in good order, and will probably stand for many years to come.

Our standards are, I believe, the same as those in the possession of the other States, and include the balances, weights, and measures distributed by the Office of Weights and Measures about 1854, besides a set of metric standards of comparatively recent date. It has seemed to me that the old standards must have been of much better material and finish than the later metric standards, or else these last have been abused. At any rate, they have been so corroded that their value as standards is impaired, while the older weights and measures are still in good, if not perfect, condition. I was amused upon hearing of the fate of the set of standards sent by this Government to Siam, as narrated by Mr. Fischer. I can report a happier situation with reference to the standards presented the French Government. Some years ago, while strolling through the Conservatoire des Arts et Métiers, in Paris, I came upon these standards beautifully displayed in glass cases, along with a series of Foucault's gyroscopes and other instruments. They seemed like old friends, you may be sure.

The laws of Iowa with reference to weights and measures are, like those of other States, exceedingly lax. With us there is nothing obligatory. It is merely specified that the State superintendent is to furnish counties and cities such standards as they may require, these to be compared with the United States standards in his possession. Neither the counties nor the cities are compelled to procure standards. The statutes provide, moreover, that the board of supervisors of any county, or the council of any town, may appoint a sealer of weights and measures to hold office at the pleasure of the appointing power. I do not know, however, of more than three or four of the 99 counties in Iowa in which the provisions of the statute have been followed, and in these cases the duties of the office have been added to those of the county treasurer or of the superintendent of schools. Some of the larger towns have made 
occasional efforts to secure some sort of general inspection, particularly of public scales, but have in no case developed any effective system. The councilors do not seem willing to vote the expense necessary. At one time or another 14 of our counties have procured more or less complete sets of standards. Others may have done so, but, if so, the fact is not shown by the records in my office.

One of the provisions of the Iowa code is that once in ten years the State superintendent shall call in all standards issued to the several counties and towns and inspect them. I do not know when a previous inspection was made, but about seven years ago, after I had been in the office for ten years, I made a conscientious attempt to comply with this requirement of the code, and issued notices to the auditors of the several counties to that end. Less than one-half of these officers responded. Of those replying, the great majority knew nothing about the matter. Some of them had heard something about a set of standards, but did not know where they were to be found. In a few instances only the standards were returned to Iowa City, as directed. The condition in which they arrived was such as to discourage any further attempts to induce the purchase of sets of standards, at least by the counties. Some of the others looked as though they had seen service in the granary or cellar, and there was apparently no consciousness that they had been misused so long as they were still intact. The officers who had had charge of them had evidently had no conception of the difference between a standard and a commercial measure or weight, and this is, of course, perfectly natural, considering that they could have had no instruction in the matter.

Our enlightened governor has shown from the first an interest in the action taken by the Bureau of Standards, which has led to our assembling here. Upon his recommendation, and with his assistance, an item was introduced among the minor appropriations made by our last legislature providing for the expenses of this delegation. It will not be difficult, I foresee, to interest a future legislature in the matter, and if this movement is pushed I am confident that the State of Iowa will be found in sympathy with it as soon as it is understood. Personally, I shall do all in my power to aid the Bureau of Standards in its efforts to secure in Iowa more general inspection and such legislation as may be found most desirable for the country at large. The time will presently come, I hope, when it will be necessary for me to lay down the office in my own State, in order to make way for some one whose other interests are not dominant, for some one with the necessary scientific training and endowed with the 
energy and executive ability essential to successful administration. I thank you.

AFTERNOON SESSION.

Dr. Stratron. We regret very much that the Hon. D. Linn Gooch, representing the State of Kentucky, was not able to remain for the afternoon session and give us some idea of the condition of affairs in Kentucky. We would like now to hear from Mr. Fowler, of Michigan.

Remarks of Mr. W. H. Fowler, Deputy State Treasurer, representing the State of Michigan.

Mr. Chairman and Gentlemen: I did not come prepared to make any remarks. I have but little to say at the present time.

In Michigan there is not very much attention paid to State inspection of weights and measures. Under an old statute the State treasurer is the State sealer of weights and measures, and I have been occupying the position of deputy State treasurer for the past four years. The State treasurer's salary is so very small, unfortunately, fixed in the constitution of Michigan, that active work of the department devolves largely upon the deputy.

When I went there as deputy we had a room in connection with our department. (By the way, I will say that there is one thing in Michigan we feel quite proud of. We have a very good building at Lansing. It was built with an appropriation of a million and a half. It is one of the things that could be recommended to many building commissioners. It was very well built, and about $\$ 28,000$ of the original appropriation returned to the State. It is one of the red-letter marks of our State-a government building put up within the appropriation.) IVe have a room with a set of weights and measures and testing scales. Whether they are positively accurate or not I do not know. Whether they are the set that Mr. Fischer spoke of, I don't know, but they have been kept in good condition and look very well.

In the past four years I have not had more than five or six sets of weights and measures to test and seal. The Michigan law is shown in this compilation that has been prepared by the Bureau. It is provided in the statute that the State treasurer should inspect and seal for the counties, and that the counties should have their sets reinspected once in five years. There is no record kept of county testing. I do not know of any sets received back for reinspection. The five 
or six that we have inspected, as I now recall, were most of them for cities. I have had some correspondence with county officials, and have told them that if they would procure sets of weights and measures, and have them sent to us, we would inspect and seal them and reship to them. Very little has been done about it. Detroit and Grand Rapids both have city sealers of weights and measures, and both have sent us sets for inspection. Grand Rapids during the past year revived an old statute appointing a city sealer of weights and measures, and he had a fairly complete set sent to us for inspection. I noticed in the Grand Rapids papers that he took up quite an active campaign in going about among storekeepers and getting after peddlers. In several cases he found street peddler's using under-size measures for peddling vegetables and fruit. Michigan is a great fruit-producing State. A good deal is peddled and shipped away, berries and peaches especially. They are shipped in boxes and baskets very largely. The sealer of weights and measures in Grand Rapids has recently resigned his position. The mayor has taken the stand that he would not appoint a city sealer; that the work could be done by the police department without extra expense to the city, so I do not think they are very much agitated there over the subject.

A steel die is used by us with the letter "M," and it is provided that weights and measures shall be stamped with that die. I have sometimes thought that it would be certainly very easy for somebody else to get a duplicate of it, and we could not tell afterwards whether we or some one else did the stamping. It seems to me that if we are endeavoring to get up a uniform system, something that had more character to it and showed to the general observer more definitely that it was an official inspection, could be gotten out, rather than something so very indefinite as stamping a letter with a steel die.

Mr. PALmer. That is a very good suggestion about having a uniform seal. We found our law defective in this respect, so the legislature adopted a regulation that all stamps should he approved by the State department.

Professor WeLd. One of the provisions of the statutes in Iowa is to the effect that when the State sealer inspects a weight he shall put upon it such private marks as may enable him in future to identify it.

Mr. Fownler. No record has been kept. There is no provision for fees, although therc is in the law for county inspection. I inquired when I went there as to what fee ought to be charged. If no statutory fee exists, the State official shall charge such fee as seems right 
and compensatory for the work. I would like to ask, Mr. Palmer, if you have a regular fee for testing county weights?

Mr. Palmer. No, sir; we do not. Previous to 1890 fees were paid by the cities and towns. At present all work performed by the State officers is free.

Mr. Fowler. I have followed largely the fees I found by inquiry were charged by previous administrations. We have charged $\$ 15$ for inspection and sealing of complete sets. I would like to hear from Dr. Stratton as to what he thinks the fee should be. I agree with Mr. Palmer that it ought to be done at the general expense of the State, or of the county, instead of charging a fee in any case.

Dr. Strattox. This Bureau does not charge any fee for State inspection. The work done for the State, or for State educational institutions, or for any State institution, is done free. The State should do the same for the counties and cities. I have never known the charging of fees to be a success, and have never found a sealer who had to do with fees who did not wish it was the other way. That is one of the subjects we ought to discuss here.

Mr. Fischer. If I am not mistaken. the salary of the sealer of weights and measures in the District of Columbia was changed from a fee to a salary basis just prior to the appointment of the present incumbent.

Remarks of Mr. IsaAc B. Brown, Secretary of Internal Affairs, and ex officio State Officer of Weights and Measures of the State of Pennsylvania.

Mr. Chairmax and Gentlemex: In the official duties imposed upon me as an officer of Pennsylvania I have but little to do with weights and measures. Briefly, however, I will say that in $183 \pm$ a law was passed by our legislature authorizing the appointment of sealers of weights and measures in the several counties of the Commonwealth.

Under the National law, standards were furnished and were kept, as provided by our Pennsylvania statutes, in the custody of the secretary of the Commonwealth. I know but little of the difficulties which may have been encountered in the administration of the laws of our Commonwealth in regard to inspectors of weights and measures.

However, the law and the manner in which it was executed had become unpopular, and its repeal was effected by the legislature of 
1883. The commercial affairs of the State moved on uninterruptedly. However, there may have been many short weights and many wrongs perpetrated in the use of scales and measures.

In 1895 the legislature provided for the appointment by the governor of inspectors of weights and measures in cities of the first and second classes. The cities covered by this act are Philadelphia, Pittsburg, Allegheny, and Scranton. The act was defective in three different ways: First, I believed it to be unconstitutional, as it was local legislation within the prohibiting clause of the constitution, which makes it illegal to pass any local law affecting cities, boroughs, and townships, or creating any legal or special offices for such municipalities. It was again defective in that the amount of money appropriated was not sufficient to procure the equipment for the inspectors of weights and measures. It was again defective in that no provision was made for standardizing the equipment which might be purchased for the use of inspectors of weights and measures in these cities.

These defects will be apparent to you when I say that it would cost about $\$ 15,000$ to buy the necessary equipment and the amount appropriated was only $\$ 2,500$.

Again, the United States standards which had been furnished by the Government of the United States had been destroyed by fire at the time of the destruction of the State capitol. And as the State law required that this National equipment should be used to standardize the equipment which might be furnished inspectors, it will also be seen how difficult, and I may say impossible, to execute our law. The duties with reference to the purchasing of the equipment were imposed upon the secretary of internal affairs, an office which I have the honor of holding.

I made every possible effort to execute the law, though from the first I believed it to be unconstitutional. I corresponded with the manufacturers of weights and measures, and I had no little correspondence with the United States Bureau of Standards. I had no money appropriated, either to buy a new set of United States standards, which would cost $\$ 550$, nor had I any means or authority of getting the equipment I might purchase standardized under United States authority or by any authority.

Political pressure was brought to bear compelling me to furnish the equipment to inspectors of weights and measures, who had already been appointed by the governor. This pressure was carried to such an extent that the attorney-general of Pennsylvania commenced mandamus proceedings to compel me to purchase the equipment, that the appointees might be able to proceed with the discharge of their duties; 
and last, but not least, to enable them to draw salaries, which they so much wanted. This want is quite common to all of us.

In due process the case was taken into our courts, and the opinion of the court below was that the act was unconstitutional and that I was justified in refusing to execute the law. I have understood that the case has been appealed to the supreme court; however, the paper book on the part of the attorney-general has not been furnished me.

I refer to these matters to indicate to you that the situation in Pennsylvania with reference to weights and measures is by no means satisfactory.

I listened with great pleasure to the paper read on the subject of the history and development of the laws with reference to weights and measures. The paper read was most instructive, and reflects great credit upon the energy and perseverance of the gentleman who so kindly favored this conference with his address on a subject which is becoming more important as we attempt to unravel its mysteries.

While I do not profess to fully understand the needs of the situation, it occurs to me that there should be additional legislation on the part of the National Government, and that there should be an assimilation of the laws in the several States on this very important subject.

The gentleman from Massachusetts gave us an interesting account of the operation of the law in that State, and I have no doubt but that the law to which he refer's is practically perfect, for the people of Massachusetts well know what the right thing is, and they know full well how to do it.

I think that this organization should be permanently effected, to the end that there may be annual meetings of the proper representatives of the different States of the Union with the officers of this National Bureau of Standards, its purpose being to effect an assimilation of the State laws and to assist in the passage of a proper national law.

A committee should be appointed at this session, emporvered to prepare and report at the next meeting of this purposed association such legislation as will insure uniformity in the several States. That this Government has existed all these years, with its wonderful and now limitless commercial interests, with these laws relating to weights and measures in such incongruous, inconsistent, and inequitable condition is truly astounding.

In my capacity as secretary of internal affairs I have been called into conference every year since 1889 on the question of National and State supervision of railroads and transportation corporations. 
To-day the establishing of rates of a uniform and reasonable character is a question of paramount issue in National legislation. These questions are difficult of solution, wherein is involved the establishing of a division line between State and National supervision. It will be less difficult to establish a proper line between National and State supervision over weights and measures than it is to establish such lines on questions involving the transportation of persons and commodities.

Mr. Chairman, we will have done great service to the States which we represent if we shall succeed in establishing uniform laws in the several States and be able to arrive at a consensus of opinion with reference to suggesting to the National Congress a bill giving proper scope and authority to the officers of the National Bureau of Standards.

Dr. Stratron. I am sure we all agree with what Mr. Brown has said. The point he brought out with regard to the line between National and State affairs has concerned us a great deal. We have given much thought to this subject, but, as he stated, I think that the line is going to be more easily drawn here than in almost any other of our public affairs. I am sure we are very greatly indebted to Mr. Brown for a number of very valuable suggestions. We should like now to hear from Mr. Richardson, of Virginia.

Remarks of Mr. John IV. Richardoson, Register of the Virginiu Land Office and ex officio Superintendent of Weights and Measures.

Mr. Chairman and Gentlemen: In a convention of State sealers of weights and measures, to consider and confer upon better methods of giving the people a simpler and more correct system of testing the scales and measures they are forced to purchase by, I deeply regret that my section is so poorly represented. Aside from $\mathrm{Mr}$. Gooch, member of Congress from Kentucky, representing his State sealer, I am, I believe, the only representative from the entire South.

In Virginia the register of the land office is ex officio superintendent of weights and measures, and having been elected register in 1897, I, by virtue of that office, became superintendent of weights and measures, and took charge March 1 of that year. In an examination of the law bearing on the actions of the office I found that the office had once been a separate State department with a salary attached, and that its duties had since been dumped into the lap of the register 
of the land office, with the salary appendix cut off. Of course that made no difference in my attention to its duties when there were any to perform, and I will here state they were few and far between.

My recollection now is that since I took charge of the office I have been called on by one county sealer for a set of weights and measures, which was shipped from the supply, hoary with age from long confinement in the dingy and dark recesses of the basement of the capitol. I suppose that other county sealers have been previously supplied, and if not, that but little or no attention is being given to the testing of measures and scales. Our system seems to me to be inadequate, clumsy, and complex, and I trust that at this or future meetings of State sealers some simple, uniform, and efficient system of testing will be suggested, and the sereral States be asked to adopt and enact the same into law. I would suggest in this connection that it be made obligatory on each State to purchase for their sealers from the United States Bureau of Standards a complete set of up-to-date testing apparatus, which shall be tested and put in order by some officer from the Bureau of Standards, upon request of State sealers, at the cost of the State.

Virginia law requires the testing outfits furnished to county sealers to be manufactured within the State. This is an error, and a new set of laws on the subject should contain a section requiring that these supplies be purchased through the United States Director and Superintendent of the Bureau of Standards, who, by having them all manufactured by one firm, can furnish them at much less cost than they could otherwise be obtained.

Under our law, measures and weights are only required to be tested and sealed erery ten years from the time they were at first sealed. This is a farce and this law should be wiped out.

It is no wonder that people complain about short weights when for a space of ten years the owners and users of measures and scales are immune from inspection and testing.

You have observed from the laws I have called attention to how inadequate they are, and can readily see in how great need my State is for better laws regulating the testing and sealing of measures and scales.

I hope that the States here represented to-day and all those that will hear of this meeting will be awakened to the need of a better system, and will at the next conrention of State sealers have their representatives present, ready to join hands in formulating and getting a better system enacted into law. 
If inspection and testing of measures and scales is worth anything to the public, it should be done in a proper manner and by competent officials, paid a fair salary. In my State the superintendent gets no salary, and the county sealers almost nothing; and hence with poor laws, poor salary, and, consequently, poor sealers, how can we expect a satisfactory job?

The attendance upon this meeting, though small, is gratifying, in that it shows that some interest is being felt in this important subject, and I hope with this nucleus for a start, and the report that will go out from this meeting to the sealers of States not here represented, that we will have a sealer present from every Commonwealth in the Union at our next meeting, and that all hands will pull together for the enactment of better laws bearing on testing and sealing measures and scales.

Dr. Stratrox. He has brought out one point there that the Bureau has often come in contact with, and that is that it is very difficult to procure proper weights and measures to be used as standards by the State and city officials. We continually receive letters from these officials asking whether they can get sets of standards, and where. Different makers have designed weights and measures according to the demand for them, but there has been nothing manufactured in the way of a simple, accurate, cheap standard, especially of capacity measures and weights-nothing between rough cast-iron weights and finer weights used by chemists.

About a year ago the Bureau undertook the design of a set of these standards, had some made first, and tried them and modified them. Finally the Bureau gave the plans of these weights and measures to the different makers. I believe one has an exhibit here. Still, much is to be done. It is difficult, as two gentlemen have brought out to-day, to procure these standards at a reasonable price anywhere to-day. I would now like to hear from Mr. Haskell, sealer of the District of Columbia.

Remarks of Mr. W. C. Hasinel, Sealer of T'eights and Measures of the District of Columbia.

Mr. Chatriran axd Gextlumex: I have been very much interested in the exchange of views and suggestions made at this meeting, and believe much benefit is to be derived therefrom. 
In the District of Columbia the sealing of weights, scales, and measures is compulsory, and no person can sell or offer for sale lawfully, anywhere in the District, any merchandise unless the same shall have been weighed or measured in scales or measures which have been duly inspected and sealed by the sealer or assistant sealer of weights and measures. Heavy fines are imposed for violation of the law. The number of measures, scales, and weights which do not conform to the standards, and which find their way into use each year, is very large. To illustrate, we have condemned and destroyed on an average of about 1,000 pieces each year of my incumbency. To be exact, 5,472 pieces have been seized and destroyed during the past five years. If we had destroyed all the scales that we found out of order or weighing incorrectly, the number would have been largely increased. We repair such scales as we can, and those we can not are labeled "Condemned for repair" and left with the owner a short time, after which, if he has not caused the repairs to be made, the scale is confiscated. These scales are usually from 1 to 3 ounces deficient to the pound, which, in the aggregate, amounts to a very considerable loss to the consumer, and this loss usually falls upon the people who can least afford it. After seven years' experience as sealer of weights and measures $I$ can not express myself too emphatically relative to the necessity of a supervision by public officials of all scales, weights, and measures used in weighing or measuring, and such an office is of much more importance to the merchant and the public than is usually conceded it.

Mr. Richardson. May I ask you a question? Do you believe that sealing and stamping causes the dealer to be honest after you leave him?

Mr. Haskeld. Sealing and stamping does not necessarily cause a dealer to be honest after we leave him. If, however, he does then violate the law, we know that it is not through ignorance, but with intent to defraud, and we immediately proceed against him in the police court. If we have any reason to believe that he will manipulate his scale after we leave we keep him in mind, and return in a few days and observe the conditions at his store. Activity and diligence are necessary to cope with the many ingenious methods resorted to in an attempt, on the part of some dealers, to deceive and defraud the public.

The office is also charged with the inspection of the weight of coal, 
and is authorized to take up coal carts, or wagons loaded with coal, anywhere in the street and demand the certificate which the law requires each dealer to send out with the load, showing the gross, tare, and net weights, and to verify the weights shown. When a shortage is found, which indicates intent to defraud, the case is reported and information filed in the police court.

The office of the sealer of weights and measures in the District is a salaried one, which, I think, is much better than if it were operated under the fee system-that is, retaining fees collected for services. Fees are collected for stamping measures, scales, and weights, under a schedule arranged by the honorable Commissioners, and these collections are deposited as are other revenues of the District.

Mr. Richardson. The only way to prevent the use of false measures is by frequent inspection.

Mr. HASKelL. Frequent inspections are an aid in preventing the use of false scales and measures. Our inspection of scales is made semiannually, and it requires practically six months to cover all the inspections in the District. We have routes laid out for each day, and record cards showing the places to be visited. These cards are so arranged that they record the inspections for five years, so that when we visit a place of business we have before us a record of the number of scales due for inspection and also the conditions of same at the previous visits.

Mr. Richardson. That is getting to a practical point.

Mr. Haskell. A receipt for the amount collected is given. The sealer of weights and measures has also been given the immediate supervision of the District markets, three in number, and the market masters; public hay scales and weighmasters of same, and the inspectors of lumber, wood, flour, and steam boilers.

A Delegate. Have you ever found cases where scales are long in weight?

Mr. Hasirell. Yes; we frequently find scales weighing against the dealer, and we are quite as careful to correct them as the scales which are short in weight. Hay scales and wagon scales are inspected semiannually, and a certificate of inspection, showing the condition of the scale, is placed on it. If we find that they are not weighing within 
the tolerance allowed, the scale is condemned for repair and must be repaired and approved by the sealer or his assistant before it is again used.

A Delegate. What does the system cost the District of Columbia? Mr. Haskell. In salaries, $\$ 6,080$.

A Delegate. That does not include the sealers or the inspectors?

Mr. Haskent. Yes, sir. The salary of the sealer is $\$ 2,500$. There is an assistant sealer at $\$ 1,200$, one at $\$ 900$, a clerk at $\$ 1,000$, and a laborer at $\$ 480$. The salaries of the market masters are appropriated by Congress, as are the salaries of the officials mentioned. The inspectors of wood are paid 9 cents per cord, and the lumber inspectors receive 30 cents per thousand feet measured, for their services. The law clearly specifies how wood shall be corded, and all wood that comes into the city for sale is corded under the supervision of the inspector. Amendments to our laws have been recommended to Congress by the honorable Commissioners. National legislation, followed by State legislation of a uniform character, is very essential. I am of the opinion that the size of a barrel in which potatoes and apples are shipped should be the same size throughout the country.

Mr. Richardson. The same size as in Richmond, Va.?

Mr. Haskell. Yes, sir. There should be a standard size for all original packages of fruits and vegetables shipped to commission merchants.

Mr. Ricinardson. Where do you get your standards?

Mr. Haskel.. From the Bureau of Standards, in the city of Washington, where we send our weights and scales to be adjusted when it is necessary to do so. A permanent organization of State sealers would result in much good, I am sure, and I hope that a uniform system of weights and measures, and inspection and sealing of same, may be adopted. I extend an invitation to the gentlemen present to call at my office, where I can show them a collection of false scales and measures confiscated during the past three months, which will be a practical demonstration of the work we accomplish and of the benefits to be derived from a supervision of scales, weights, and measures. 
Mr. Richardson. Let the Bureau of Standards wait on us all.

Dr. Stratton. That's just what the Bureau is for.

Mr. Fowler. Mr. Richardson's remark concerning the small fees allowed for testing weights and measures made me refer to the Michigan law, where the township clerk is sealer of weights and measures. Some time in the month of April he posts a written notice for the people to bring weights and measures to be tested, and the law provides the liberal compensation for trying, proving, and sealing of 3 cents for each scale found not to be proper and 2 cents for each scale found to be proper.

Mr. Richardson. I see more and more the need of this meeting.

Mr. Fowler. In another place it says: "Once in every year he shall go to the houses, stores, and shops, where they do not come to him, and for such service he shall receive double the fees and 4 cents a mile mileage." If he had to carry our weights and measures (they are not quite as heavy as yours, Mr. Richardson) I don't think the sealer would ever get very wealthy.

Mr. Palmer. Mr. Chairman, I believe in union there is strength; at least we find it so in Massachusetts. We have county organizations. We have State organizations of sealers of weights and measures. They meet once each year to formulate plans of legislation, and it has proved of great assistance in the passage of legislation. It makes everybody interested. Each sealer sees his representative, and in that way we are able to pass legislation with very little opposition. It seems to me, from the remarks that have been made, that there seems to be a necessity for an organization in order to produce the results we want to produce, and I move, Mr. Chairman, that we take steps toward the organization of a national body, composed of sealers of weights and measures of the various States, in order that we can have a national organization of this kind. I would leave it to the chair as to the methods of organization. We might appoint a committee to draw up a preliminary plan and adopt it to-morrow morning. But I make the motion.

The motion was seconded by Mr. Haskell.

The Chairian. It has been moved that steps be taken toward effecting a permanent organization. 
Mr. Palarer. I understood several were to go away, and I thought perhaps we could appoint a subcommittee, and you probably had some idea. In fact, I suggest that you be chairman of the committee to adopt some method which the association, or such members as are here now or will be here to-morrow morning, could talk over and adopt at that time.

Dr. Stratton. I would say that we had nothing at all in mind, except that we would like very much to continue these meetings. We would like to have the State officials meet here every year, and will leave the details of organization in your hands. It seems to me that it is very evident that we could bring about uniform State legislation, or National legislation. Some National legislation is necessary and also some State legislation. Furthermore, every State is entitled to the services of the Bureau. The Bureau can not go into the testing of weights and measures locally, although that might be handled by means of substations. We could, however, easily arrange some plan of cooperation and bring about whatever legislation is necessary. The Bureau should, of course, test the standards. I have sometimes thought that at the outset State arrangements for testing or sealing need not be provided. An efficient State inspector could see to it that the local officials were carrying out the law. He would inspect and supervise the work of the local officers and be the intermediary between the Bureau and the local authorities. There is no reason why every State should not handle this matter efficiently and withont great expense. It would need in each State an official who has a respectable salary and who would be just as important as any other State official, and that this official should look after legislation in his State and see that the different counties or cities avail themselves of the services of this Bureau or of the State office of weights and measures where it exists. Something should be done at once. Remarkable as have been the statements made to-day we have not heard the worst, as there are States in which absolutely nothing is done and which are not represented here to-day.

Mr. Brown. I presume it is the purpose of the mover of the resolution to include in this organization the sealers of weights and 
measures, or other officers in the States charged with similar duties, together with the Bureau of Standards of the National Government.

Mr. Palmer. Yes, sir.

Mr. Fischer. I would like to inquire as to the status of Mr. Haskell, as the District has a rather special relation to the National Government; but I suppose there is no question but that he would come in as a State officer.

Mr. Haskell. Half of the expense of the office of sealer is paid by the General Government and half by the District. I am considered, however, as a District officer.

The motion for the appointment of a committee was then carried.

The committee appointed consisted of the chairman, Mr. D. C. V. Palmer, Mr. P. F. Hazen, Prof. L. G. Weld, Mr. W. H. Fowler, and Mr. L. A. Fischer.

Remarks of Mr. Perley F. Hazen, representing the State of Vermont.

We all seem to be in about the same situation to-day in that we came here not knowing exactly what this meeting was for, and hence not prepared to make definite suggestions. I expect that in whatever we say we shall all wish recourse to the prayer book wherein we read: "We have said many things we ought not to have said, and have left unsaid many things we ought to have said."

I am in somewhat of an embarrassing position, not being a State sealer or a custodian of State or municipal weights and measures, but am connected with a corporation which manufactures such articles. When the invitation came to Vermont to send a delegate to this convention, the governor, evidently not knowing whom to send, asked if $I$ would accept an appointment, to which an affirmative reply was made, and that is why I am here. As I say, I am in a somewhat embarrassing position, as any suggestions concerning the character of weighing machines or measures which shonld be employed might be construed as trying in a cheap way to advertise the business with which I am connected. I assure you, however, that this is furthest from my desire.

I do not think I am quite in sympathy with the work of this Bureau of Standards. Every section has its object of local pride, concerning which it can boast, and in northeastern Vermont it is its winter weather. With thermometers varying from 10 to 15 degrees, and some 
cold-morning reports are received of the mercury registering from 35 to 50 degrees below zero, we of course always make use of the lowest record. It makes better headlines in the newspapers and causes more shivering on the part of those who read. I am afraid this standardizing bureau will do a way with all that, and that we Vermonters will not get as much glory as heretofore.

But I assure you that I am heartily in sympathy with the subject which has been discussed and with all that has been said here to-day. The purchasing public is too much at the mercy of users of unreliable weighing machines and capacity measures, and of unscrupulous manipulators of even correct ones. The law in Vermont appears to be just about like that in other States, and is practically a dead letter. The state treasurer has the care of the standard weights and measures, furnished by the Gorernment, of which we have heard to-day, and these are kept at the State capitol. This treasurer is the cashier of a bank, an excellent business man, and a thoroughgoing accountant; but of course he knows little, if anything, about weights and measures, nor is he expected to as a mere custodian of them. In his businesslike way, however, he not long ago asked us to send a man over to Montpelier and make a thorough examination of the weights and measures in his care and see what could be found out about them. The law also requires that each county shall be provided with duplicate sets of weights and measures, and also that each town should have similar sets. I have never seen any of these weights and measures, and do not know where they are nor of what they consist. You may think it surprising that in a State where two of the largest scale works in the United States, and probably in the world, are situated that interest in this matter should be so slight. The sale of scales, howerer, is not in Vermont. The amount sold there would not be a drop in the bucket in the business conducted. These goods are marketed all over the United States and in foreign countries; and so it is not surprising, after all, that the subject does not have any more attention right where the goods are manufactured than elsewhere.

There comes to us incidentally, as manufacturers, a knowledge of a great many tricks resorted to by dishonest people in the use of scales and measures. One which has not been mentioned here to-day is that of a carefully made weight. The user will balance up his scale with this weight, attached to the bottom of what is technically known as the "counterpoise"-that is, the part suspended from the small end of the beam to receive the sealed weights in the process of 
weighing. When the load is placed upon the platform it is very easy for the operator, in handling the regular weights, to detach this weight from the counterpoise and slip it into his pocket. The scale will then, of course, indicate a greater load than is placed upon the platform, and the customer is thus cheated. And so there are any number of tricks that we hear about, although I have never personally seen any of them worked.

It is said that the United States post-office is twenty-five years behind the times in its methods. I am thinking that some of us who have been sitting here to-day have come to the conclusion that our system of inspection of weights and measures, after they get into the hands of users, is as much or more behind the times. We certainly need more efficient and stringent laws upon this subject. I might be able to make some suggestions of value in the compiling of data for the formulating of statutes, based upon our experience as manufacturers, but this is not the time or place to enter into a discussion of that phase of the subject. And so I will only add that I am heartily in sympathy with the taking of steps toward muchneeded legislation for better protection of the purchasing public.

Dr. Stratton. We are glad to have the practical experience of a manufacturer. Next year we hope to have exhibits of various instruments. It is a very important problem to determine what the sealer should have, and we must have the cooperation of the manufacturer. We never manufacture anything that can be bought in the market. We sometimes make weights and measures in order to try a plan, if we think we can improve them, but the moment we finish them they are given to the manufacturers. We have a very nice shop. There is none better, but we need the instrument makers for other work, experimental work, as it is not our plan to manufacture, but to cooperate with manufacturers.

$$
\text { JANUARY 17, } 1905 .
$$

Meeting of Committee on Organization.

Mr. Frscrer read a list of the States which had agreed to send delegates.

Mr. PaLmer stated that he believed Maine and Connecticut would adopt whatever legislation was recommended. 
After discussion, Mr. Palmer, on behalf of the Committee on Organization, presented the following resolution, which was adopted:

Resolved, That it is the sense of this convention that meetings of State sealers or custodians of weights and measures be held annually in Washington to discuss and facilitate both National and State legislation tending toward securing uniformity in the laws pertaining to weights and measures and their inspection throughout the United States, and the Bureau of Standards is requested to arrange such a meeting.

After discussing the matter of the next meeting it was decided that it should be held in October, unless something occurred to prevent it.

Mr. Hazen presented a resolution, extending the thanks of the convention to Dr. Stratton and Mr. Fischer for their interest in calling the meeting and the courtesies extended those present.

O 


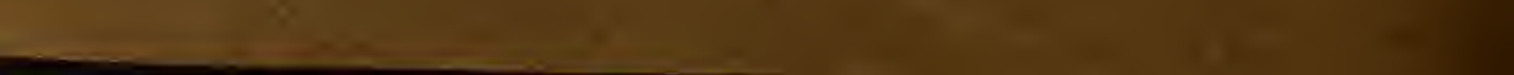

